\title{
INTERLEUKIN-6 LEVELS PREDICTS MORTALITY AFTER STROKE: A SYSTEMATIC REVIEW AND META-ANALYSIS
}

\author{
ARASH KHOJASTEH ZONOOZI ${ }^{1}$, KONSTANTINOS TSAROUHAS ${ }^{2,3}$, MOHAMMAD MAHDI \\ SOTOUDEH ${ }^{1}$, ABOLFAZL AVAN $^{4}$, RAMIN REZAEE $^{5}$, NEGAR MOROVATDAR $^{5 *}$ \\ ${ }^{1}$ Student Research Committee, Faculty of Medicine, Mashhad University of Medical Sciences, Mashhad, Iran \\ ${ }^{2}$ Department of Cardiology, University Hospital of Larissa, Larissa, Greece \\ ${ }^{3}$ Center for Adolescent Medicine and UNESCO Chair on Adolescent Health Care, First Department of Paediatrics, Medical \\ School, National and Kapodistrian University of Athens, Aghia Sophia Children's Hospital, Athens, Greece \\ ${ }^{4}$ Department of Neurology, School of Medicine, Mashhad University of Medical Sciences, Mashhad, Iran \\ ${ }^{5}$ Clinical Research Development Unit, Faculty of Medicine, Mashhad University of Medical Sciences, Mashhad, Iran
}

*corresponding author: MorovatdarN@mums.ac.ir

Manuscript received: December 2020

\begin{abstract}
The aim of this study was to evaluate the relation between stroke-related mortality and post-stroke blood levels of interleukin-6 (IL-6). PubMed, Embase, Web of Science and Scopus were systematically searched for relevant articles published up to November 2019. Cohort studies which investigated post-stroke IL-6 levels in the blood and mortality rates in patients with acute ischemic stroke or transient ischemic attack were included. Among the retrieved items, six studies were finally included in the meta-analysis. IL-6 levels were found to be associated with higher rates of mortality after stroke (adjusted relative risk [RR]: 1.55, 95\% confidence interval $[\mathrm{CI}]: 1.16-2.07 ; \mathrm{I}^{2}=73.5 \%, \mathrm{p}=0.002$ ). Subgroup analysis showed that IL-6 increases the risk of 3-month mortality (RR: 1.68, 95\% CI: 1.15 - 2.47). One study confirmed the independent prognostic value of IL- 6 for functional outcomes in these patients. Based on the present analysis, IL-6 can be considered a predictive factor for stroke-related mortality. IL-6 suppression might decrease mortality; however, this finding warrants further clinical investigations.
\end{abstract}

\section{Rezumat}

Scopul acestui studiu a fost evaluarea corelației dintre mortalitatea asociată accidentului vascular cerebral (AVC) și valorile sanguine ale interleukină-6 (IL-6) post-AVC. Bazele de date PubMed, Embase, Web of Science și Scopus au fost consultate sistematic privind articolele relevante publicate până în noiembrie 2019. Au fost incluse studii de cohortă care au investigat nivelurile IL-6 post-AVC în sânge și ratele de mortalitate la pacienții cu AVC ischemic acut sau atac ischemic tranzitoriu. Din articolele identificate, şase studii au fost incluse în meta-analiză. Nivelurile IL-6 s-au dovedit a fi asociate cu rate mai mari de mortalitate după AVC (risc relativ ajustat [RR]: 1,55, interval de încredere 95\% [CI]: 1,16 - 2,07; $\mathrm{I}^{2}=73,5 \%, \mathrm{p}=$ 0,002). Analiza subgrupurilor a arătat că IL-6 crește riscul mortalității la 3 luni (RR: 1,68,95\% CI: 1,15 - 2,47). Un studiu a confirmat valoarea prognostică independentă a IL-6 la acești pacienți. Pe baza prezentei analize, IL-6 poate fi considerat un factor predictiv al mortalității determinate de AVC. Inhibiţia IL-6 ar putea scădea mortalitatea, fiind necesare investigații clinice suplimentare.

Keywords: inflammation, IL-6, ischemic stroke, outcome, mortality

\section{Introduction}

Stroke as a high-burden disease, is globally the second leading cause of death [1-3]. Death occurs in approximately one third of stroke cases; also, one third of stroke patients experience permanent disabilities, requiring hospital care [2]. Therefore, improvement of early and precise decision-making is crucial to predict post-stroke outcomes [4]. In this context it was shown that a variety of factors including age, gender, comorbidity, severity and site of injured cerebral tissue, post-stroke infection and some other complications are associated with increased morbidity and mortality following stroke [5, 6]. Moreover, early prediction of other stroke outcomes can be considered as an interesting focus of research in this field [5, 7]. Following the initiation of inflammatory responses in the stroke-affected tissue [8], a variety of cytokines including interleukin (IL)-6 surge [4, 9]. Previous studies demonstrated a relation between high levels of inflammatory markers and short-term post-stroke mortality $[2,3,7,10]$. It has not been cleared yet if there is a probable casual relation, or mere association, between IL-6 and poor outcome after stroke. Mice with low IL-6 levels had similar stroke volume and disability after 24 hours compared with those with normal IL-6 levels [11], suggesting that it may simply be a part of an inflammatory response to stroke and not an underlying pathogenic factor. Since the association 
of IL-6 with poor outcome has been demonstrated in many conditions such as cancers [12], and vascular diseases [13], it seems to be more plausible that IL6 is a general marker of disease severity rather than playing a part in numerous disease-specific pathways resulting in poor outcome.

There is also evidence on a relation between acute phase reactants, including IL-6, and short-term mortality [4]. Assessment of long-term stroke survivors indicated IL-6 as an independent predictor of mortality [5, 14]. Besides, levels of cytokines, including IL-6, increase with increasing age and age-related disorders such as atherosclerosis, which should be contemplated as confounding factors [15].The aim of this systematic review and meta-analysis was to pool current evidence on the association of IL-6 levels with mortality after acute stroke.

\section{Materials and Methods}

\section{Search Strategy}

We searched scientific databases, including PubMed, Embase, Web of Science and Scopus, up to November 7, 2019, using the following keywords: IL-6, stroke, cerebrovascular accident, and mortality. First, two authors (A.KH.Z. and M.S.) excluded 656 citations through Titles and Abstracts review. Then, the full texts of all relevant studies and those needed deeper evaluation, were checked. A third assessor (N.M.) helped with making decision over disagreements. Also, the reference lists of relevant articles and reviews were hand-searched for missing studies.

\section{Inclusion Criteria}

In the present work, cohorts reporting post-stroke IL-6 levels in the blood and mortality rates in patients with acute ischemic stroke or transient ischemic attack were included. Of note, only studies done on humans and written in English were included and letters to editors, duplicate articles, congress abstracts and reviews were not considered.

\section{Data Extraction and Quality Assessment}

The following indices were extracted from each article: The first author's name, publication year, country where the research was done, study type, inclusion and exclusion criteria, study follow-up period and timeto-death, stroke type, number of patients, mean age (years), sex ratio and time of IL-6 measurement. Data on risk ratio or relative risk (RR), odds ratio (OR) or hazard ratio (HR) values were used to analyse the summary association between IL- 6 and mortality after stroke.
The Joanna Briggs Institute Critical Appraisal Checklist was used for evaluation of the quality of the retrieved studies [16]. Two reviewers (M.S. and A.KH.Z.) independently did data extraction and quality assessment. Another author (N.M.) checked for inconstancies between the reviewers. Studies with a score higher than 5 out of 11, were considered of "high quality" and selected for data extraction [17].

Statistical analysis

Data from individual studies were pooled using randomeffect model depending on the heterogeneity in order to assess possible associations. Adjusted RR along with $95 \%$ confidence intervals (CIs), was used. The inconsistency index $\left(\mathrm{I}^{2}\right)$ was used to measure heterogeneity, with an $\mathrm{I}^{2}>50 \%$ indicating a substantial heterogeneity. Subgroup analysis was done based on study followup period. Publication bias was assessed using Begg's test. All analyses were performed using STATA version 11 and a p-value $<0.05$ was considered statistically significant.

\section{Results and Discussion}

Scientific databases search yielded 1082 articles and after removing duplicates, Title/Abstract review was accomplished. Initially, 656 citations were excluded through the Title/Abstract review (Figure 1). After reviewing 16 full texts, 6 studies that reported adjusted $\mathrm{RR} / \mathrm{HR}$ were found eligible for the meta-analysis. The following items were eventually pooled in the analysis: five articles reported values of IL-6 in pg/mL, as the measurement unit, and one reported logarithmic value of IL-6 in ng/mL (Table I and Figure 2).

Main characteristics of the included articles are summarized in Table I. Four articles reported 3-month mortality risk [2, 3, 18, 19], and two studies had 5 years of follow-up $[14,15]$. The quality of the included articles was high as the quality scores ranged from 8 to 11 . In the meta-analysis, 2113 patients were studied. IL-6 levels were associated with increased risk of mortality (RR: $1.55,95 \% \mathrm{CI}: 1.16-2.07)$, with high heterogeneity between studies $\left(\mathrm{I}^{2}=73.5 \%, \mathrm{p}=\right.$ 0.002 ) (Figure 2). In sensitivity analysis concerning the unit of measurement of IL-6, results were not affected by excluding any of the included studies (Figure 3). Based on the follow-up period, subgroup analysis was done; the results suggested that IL-6 is associated with an increased risk of 3-month mortality $(\mathrm{RR}=1.68,95 \%$ CI: 1.15 - 2.47; Figure 4). Publication bias assessed by Begg's test indicated a $\mathrm{p}$ value of 0.3 (Figure 5). 
FARMACIA, 2021, Vol. 69, 4

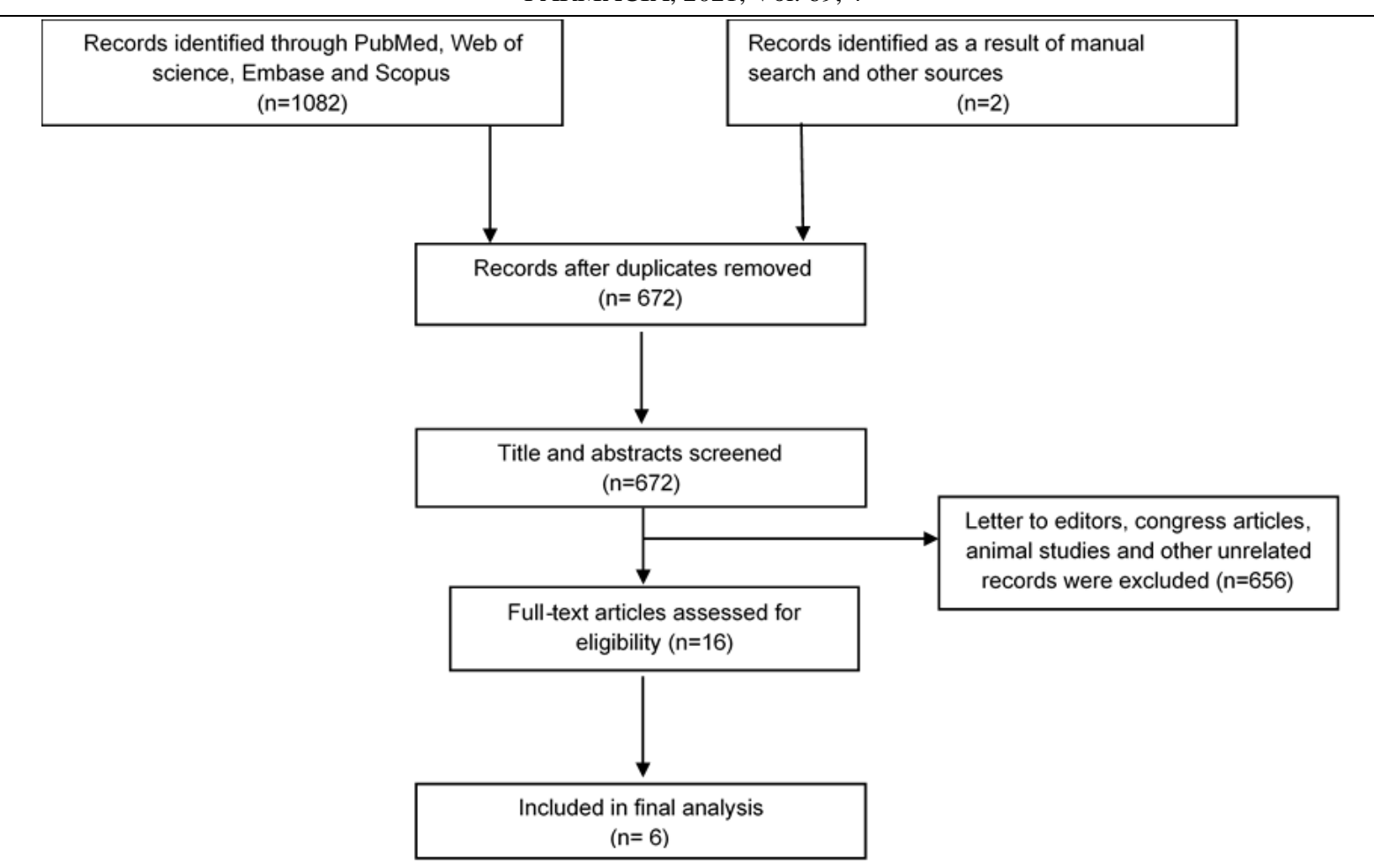

Figure 1.

PRISMA flow diagram of the study

Studies

Chamorro 2007

Gori 2017

Greisenegger 2015

Kwan 2013

Mengel 2019

Vissoci Reiche 2019

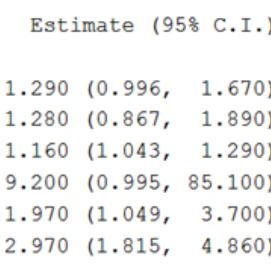

Overall (I^ $2=73.55 \%, P=0.002) \quad 1.551 \quad(1.160,2.075)$

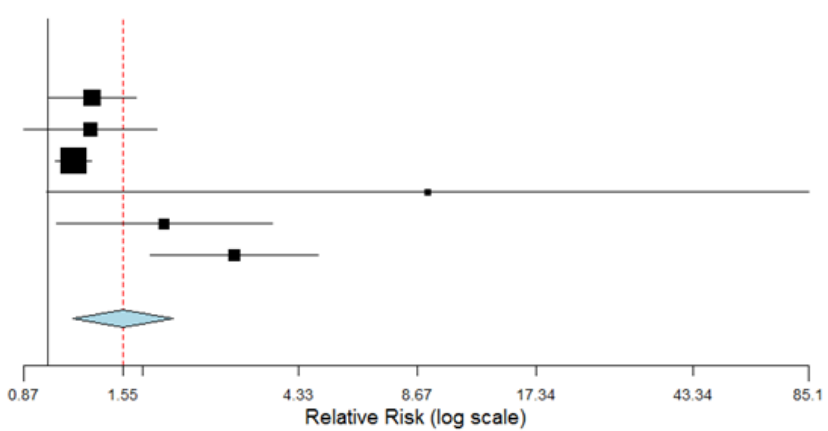

Figure 2.

Forest plot for association between IL-6 and mortality after ischemic stroke

\begin{tabular}{lll}
$\begin{array}{l}\text { Studies } \\
\text { Overall }\end{array}$ & \multicolumn{2}{l}{ Estimate $(95 \%$ C.I. $)$} \\
& $1.551(1.160,2.075)$ \\
- Chamorro & $1.737(1.125,2.683)$ \\
- Gori & 1.667 & $(1.158,2.397)$ \\
- Greisenegger & 1.783 & $(1.193,2.664)$ \\
- Kwan & 1.495 & $(1.133,1.971)$ \\
- Mengel & 1.501 & $(1.099,2.048)$ \\
- Vissoci Reiche & 1.280 & $(1.064,1.538)$
\end{tabular}

Forest plot for sensitivity analysis of association between IL-6 and mortality after ischemic stroke 
FARMACIA, 2021, Vol. 69, 4

\begin{tabular}{|c|c|c|c|}
\hline 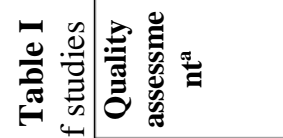 & $\vec{\sigma}$ & $\underset{\infty}{\vec{\infty}}$ & $\Xi$ \\
\hline 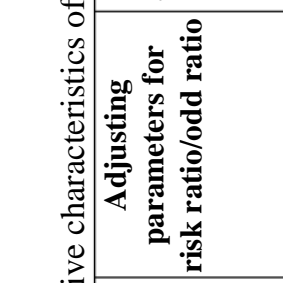 & $\frac{\mathbb{Z}}{\mathrm{z}}$ & 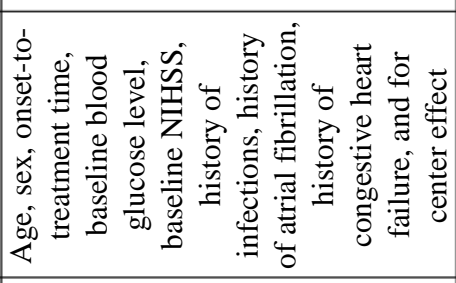 & 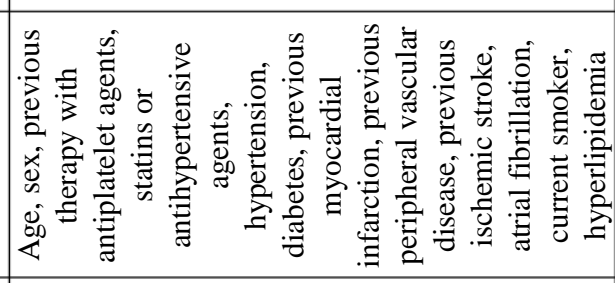 \\
\hline 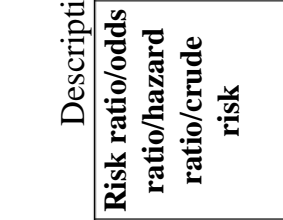 & 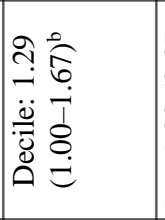 & 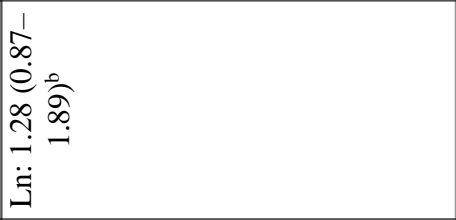 & 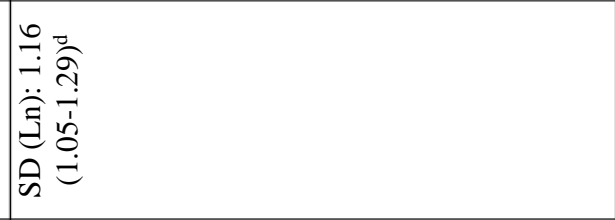 \\
\hline 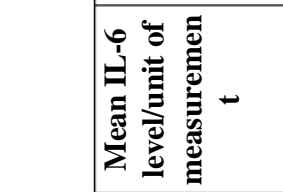 & 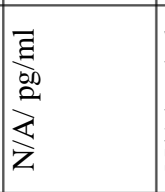 & 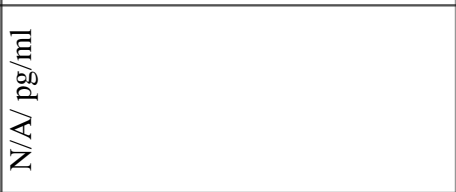 & 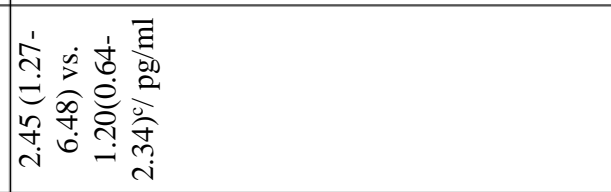 \\
\hline 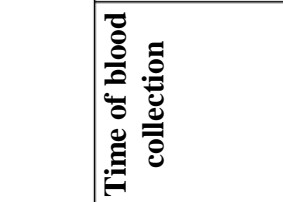 & 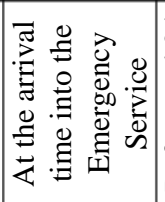 & 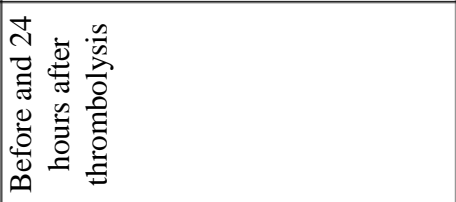 & 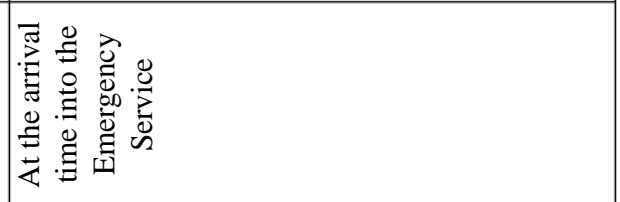 \\
\hline 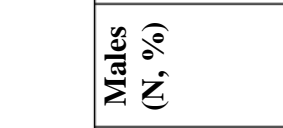 & ल & 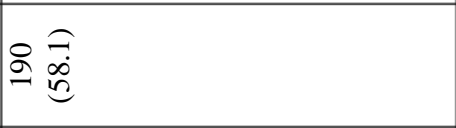 & 孚佘 \\
\hline 焉 & în & â $\frac{9}{+1}$ & 㖕n \\
\hline 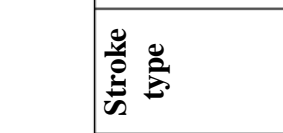 & $\frac{\rho}{\mathbb{2}}$ & $\frac{\tilde{L}}{\mathbb{2}}$ & 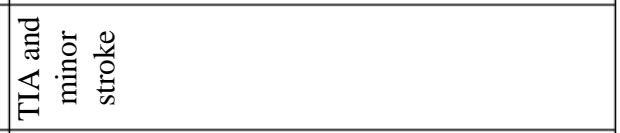 \\
\hline 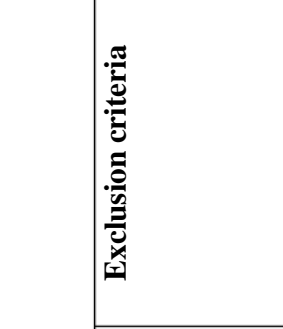 & 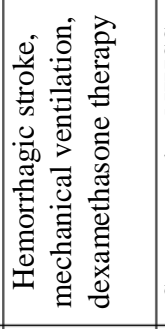 & 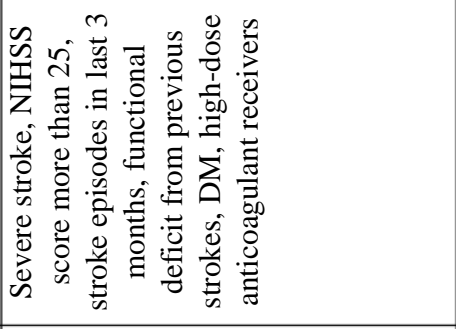 & $\frac{\widehat{z}}{\mathrm{z}}$ \\
\hline 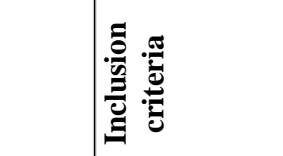 & $\frac{\tilde{z}}{\alpha}$ & $\frac{n}{4}$ & $\frac{1}{4}$ \\
\hline 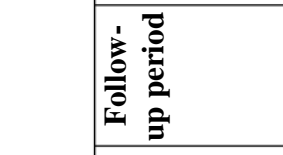 & 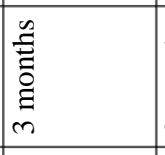 & 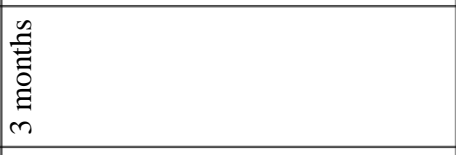 & 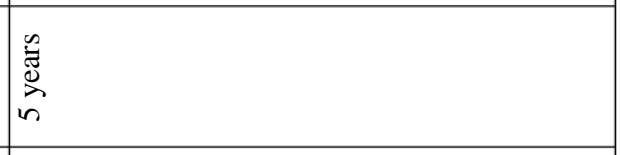 \\
\hline 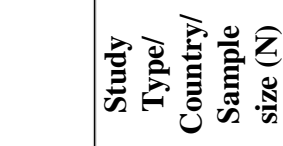 & 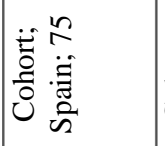 & 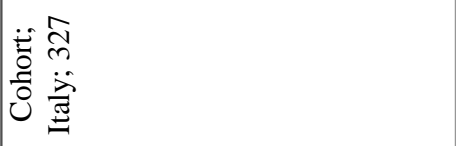 & 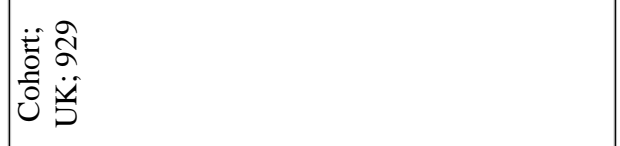 \\
\hline 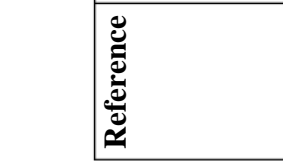 & 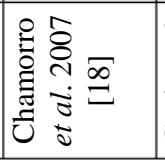 & 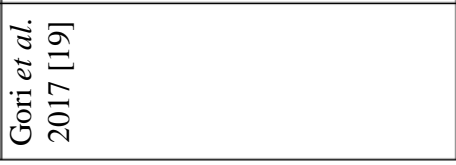 & 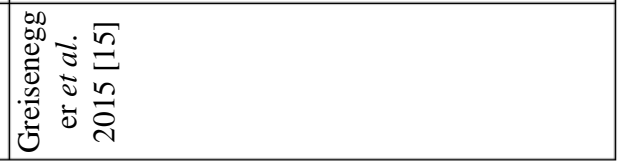 \\
\hline
\end{tabular}


FARMACIA, 2021, Vol. 69, 4

\begin{tabular}{|c|c|c|c|c|}
\hline 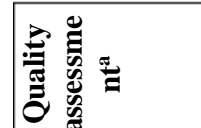 & F & Fे & $\Xi$ & \\
\hline 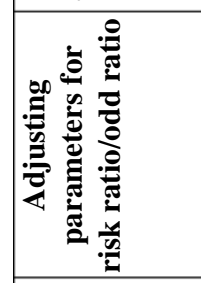 & 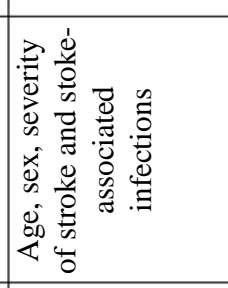 & 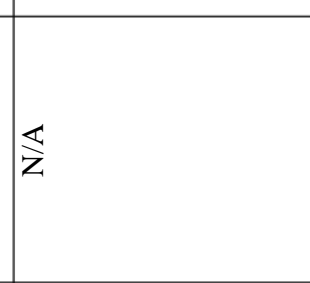 & 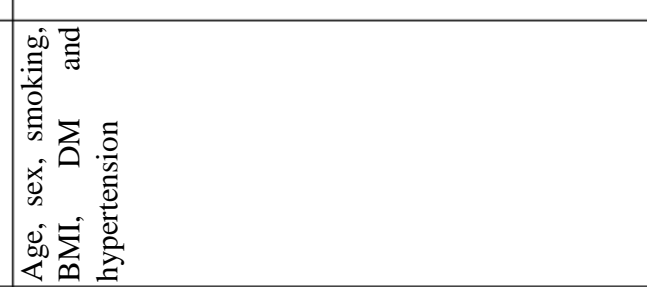 & 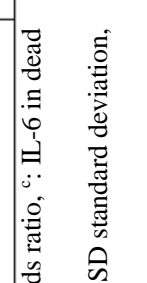 \\
\hline 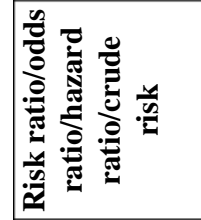 & 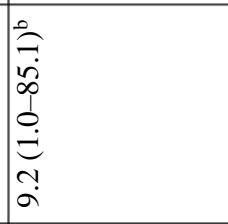 & 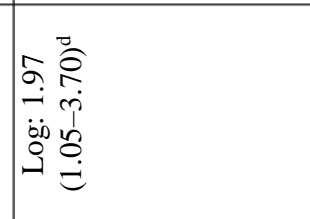 & 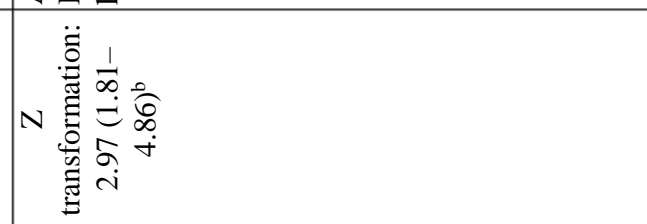 & 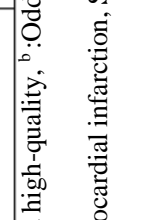 \\
\hline 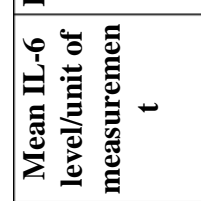 & 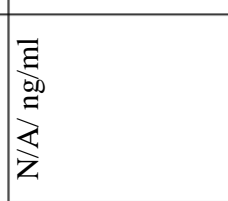 & 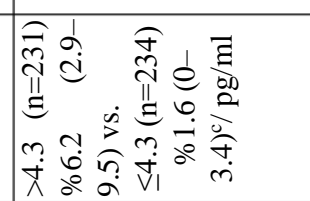 & 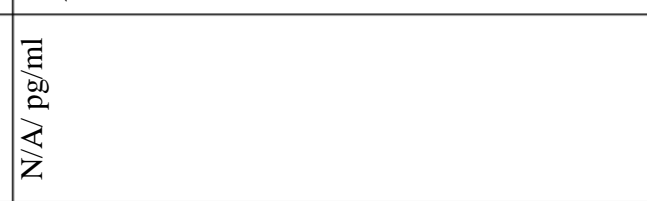 & 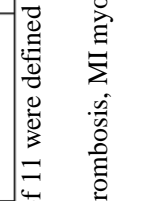 \\
\hline 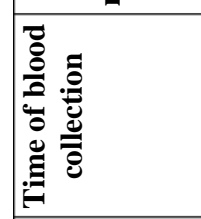 & 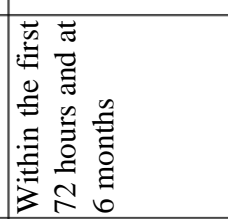 & 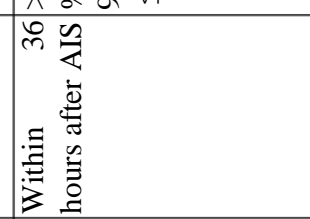 & 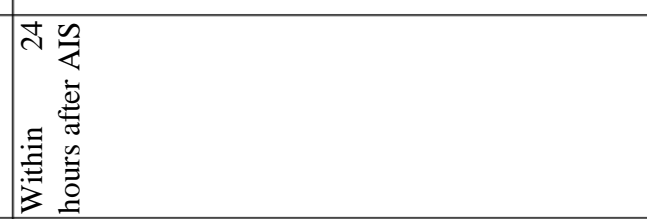 & 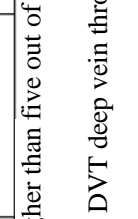 \\
\hline 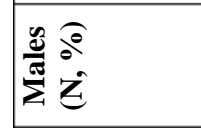 & o $\widehat{\widehat{c}}$ & 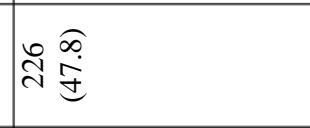 & 兽疍 & 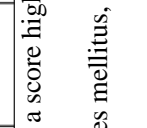 \\
\hline 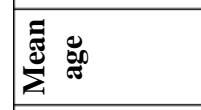 & $\begin{array}{l}+1 \\
+1 \\
\dot{I} \\
\dot{n}\end{array}$ & & $\overrightarrow{\tilde{b}}$ & \\
\hline 善兘 & $\frac{n}{4}$ & $\frac{2}{4}$ & $\frac{\Omega}{4}$ & 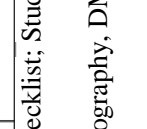 \\
\hline 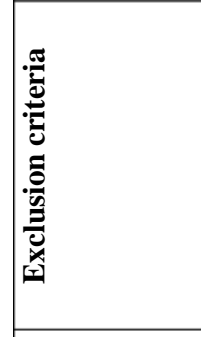 & 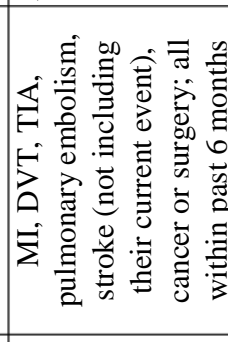 & 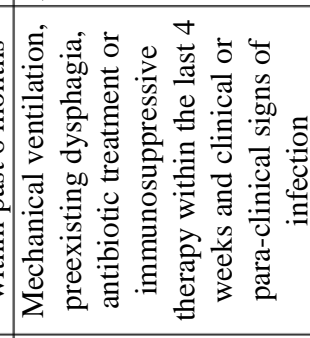 & 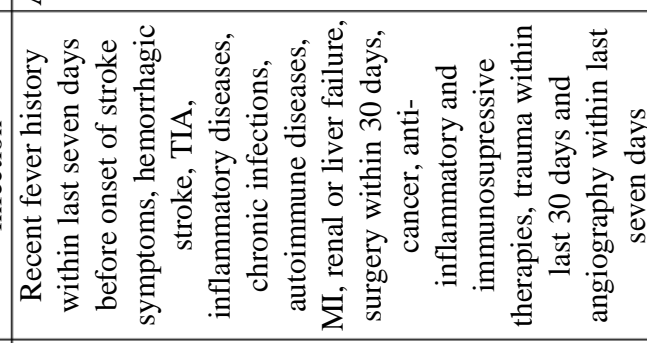 & 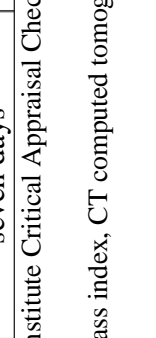 \\
\hline 施 & 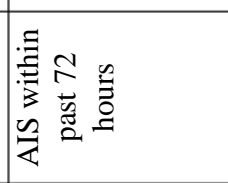 & 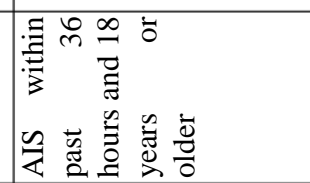 & 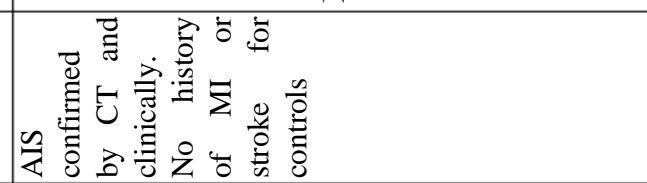 & 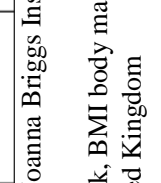 \\
\hline 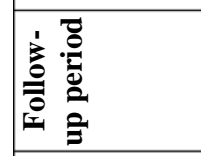 & 总 & 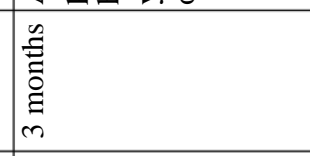 & 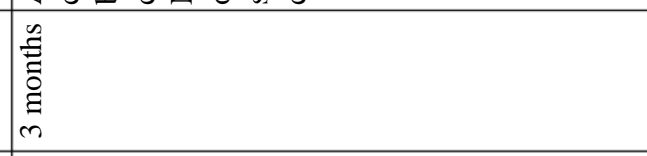 & 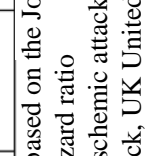 \\
\hline 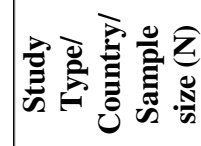 & 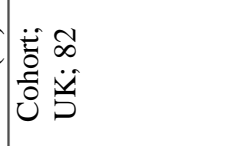 & 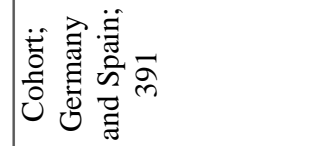 & 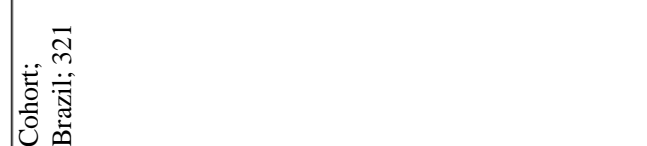 & $\begin{array}{l}0 \\
0 \\
3\end{array}$ \\
\hline 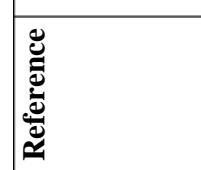 & 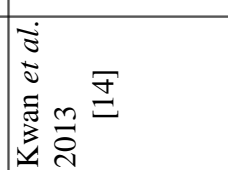 & 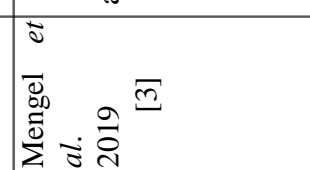 & 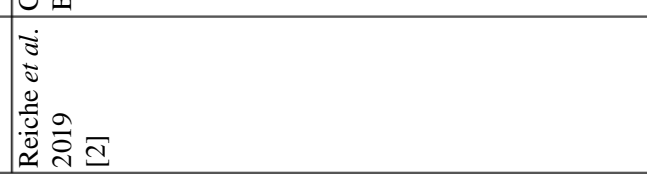 & 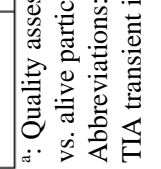 \\
\hline
\end{tabular}




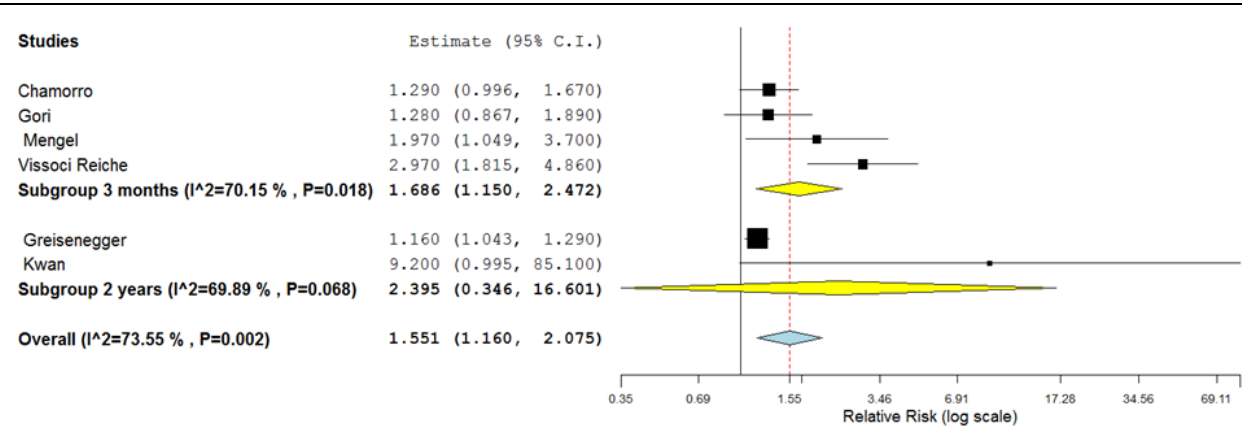

Figure 4.

Subgroup analysis of association between IL-6 and mortality after ischemic stroke based on the follow-up period

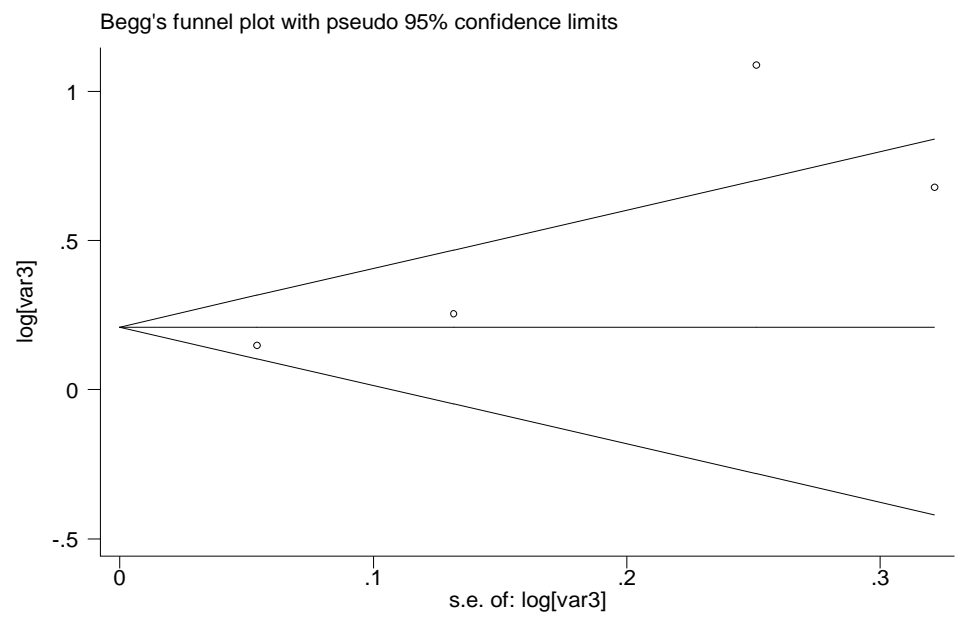

Figure 5.

Funnel plot

In the setting of acute ischemic stroke, IL-6 seems to be a cytokine of considerable importance. Its association with the production of $\mathrm{C}$-reactive protein and fibrinogen in the liver, as a response to an acute injury, seems to set the level of inflammatory response, while it is the only inflammatory biomarker that can pinpoint the aetiology of ischemic stroke due either to large or small artery occlusion at the first hours post hospital admission [20]. Inflammatory cytokines release after an acute ischemic stroke is caused by both the infiltrating inflammatory cells and the vascular endothelium. Infarct evolution is probably related to cytokines concentration in the penumbra, while IL-6 is closely related to the extent of cerebral injury [21]. The prognostic role of IL-6 levels in acute ischemic stroke seems to expand also in the setting of modern therapies implemented in these pathologic conditions, such as mechanical thrombectomy. Augmented IL6 levels at $24 \mathrm{~h}$ indicated futile reperfusion. In such cases, the link between IL- 6 and worse outcomes involves thrombotic and inflammatory pathways leading to "no reflow" phenomenon [22]. Impaired tissue reperfusion and dysfunction of blood-brain barrier (BBB) are the main mechanisms linking inflammation and poor outcome in acute ischemic stroke. Brain damage is increased by the neutrophil infiltration of cerebral cortex due to $\mathrm{BBB}$ dysfunction occurring through local inflammation, while impaired tissue reperfusion involves inflammatory cytokines' action on the endothelin-1 receptors of large brain vessels [23]. In close relation to the prognostic value of IL-6 in acute ischemic stroke are the observations in coronary artery disease, where a linear relationship of IL-6 values and cardiovascular morbidity is reported [25].

In the current systematic review and meta-analysis, six cohorts comprising 2113 patients were included; the present analysis indicates that increased IL-6 levels are associated with higher mortality rates after stroke, independent of age, sex, and stroke severity. All the six studies have found a positive correlation between increased IL-6 levels and risk of death after acute stroke. The biggest association was reported in the cohorts published by Kwan et al. $(\mathrm{N}=82)$ [14] and Reiche et al. $(\mathrm{N}=321)$ [2]; however, the lowest association was observed in the largest cohort that enrolled 929 patients [15]. Of note, the included studies varied in the follow-up periods; Chamoro et al., Gori et al., Mengel et al. and Reiche et al. [2, 3, 18, 19] reported a 3-month follow-up while Greisenegger et al. and Kwan et al. [14, 15] had 5- and 2-year followups, respectively.

Inflammation plays a key role in acute ischemic stroke [25]. Cerebral ischemia triggers an inflammatory response characterized by the up-regulation of IL-6 in the brain 
as well as the peripheral blood, suggesting a plausible role for IL-6 as a biomarker of acute brain injury [26]. In addition, IL-6 level may be elevated due to other complications such as post-stroke infections [27]. In a cohort on 721 participants, IL-6 and NT-proBNP (N-terminal-pro brain natriuretic peptide) were found as independent prognostic factors for death, in multivariate analyses [7]; in this study, authors showed that the prognostic value of IL- 6 was additive and clinically relevant to the National Institutes of Health Stroke Scale (NIHSS), indicating that IL-6-associated immuneinflammatory responses might contribute to death after acute stroke. These results added to prior evidence showing that increased peripheral levels of IL-6 and high sensitivity C-reactive protein (hsCRP) predict an increased mortality rate in individuals with serious medical conditions [24, 28, 29]. Besides, another study confirmed the independent prognostic value of IL-6 for functional outcomes in patients who experienced acute ischemic stroke [6].

Cerebral ischemia triggers the release of IL- 6 from neurons and astrocytes [30]. IL-6 levels increase in stroke patients within a few days. In patients with ischemic stroke, high IL-6 levels found in the cerebrospinal fluid and blood were found to be associated with occurrence of neurological deterioration and poor functional outcome [31, 32]. Nonetheless, some studies could not establish such associations $[4,33]$. One study showed that IL-6 levels $>13 \mathrm{pg} / \mathrm{mL}$ could predict in-hospital mortality with a sensitivity of $85 \%$ and specificity of $93 \%$. However, it should be noted that it does not prove a causal role for IL-6 as it may simply reflect an ischemic brain injury [10].

A previous meta-analysis studied the association of inflammatory factors and functional outcomes after stroke [6], while the current study is the first to report the association between IL-6 and mortality after stroke. However, our study has the following limitations: First, few studies [4, 8, 34], were excluded from analyses because they reported the crude means of the IL- 6 levels in two groups (i.e. control and study groups) rather than adjusted RRs. Second, there was a high heterogeneity among the included studies. Third, since the units of measured IL-6 varied among the studies, a pooled value with and without those data was estimated.

\section{Conclusions}

Based on the results of the current meta-analysis of the data of six cohorts, increased levels of IL-6 as an acute inflammatory response, is associated with poor survival after stroke. Therefore, IL-6 can be used as a predicting factor for stroke-related mortality. Hypothetically, IL-6 suppression might decrease mortality and this warrants further investigations.

\section{Conflict of interest}

The authors declare no conflict of interest.

\section{References}

1. Avan A, Digaleh H, Di Napoli M, Stranges S, Behrouz R, Shojaeianbabaei G, Amiri A, Tabrizi R, Mokhber N, Socioeconomic status and stroke incidence, prevalence, mortality, and worldwide burden: an ecological analysis from the Global Burden of Disease Study 2017. BMC Med., 2019; 17(1): 191-191.

2. Reiche EMV, Gelinksi JR, Alfieri DF, Flauzino T, Lehmann MF, de Araújo MCM, Lozovoy MAB, Simão ANC, de Almeida ERD, Maes M, Immune-inflammatory, oxidative stress and biochemical biomarkers predict short-term acute ischemic stroke death. Metabolic Brain Disease, 2019; 34(3): 789-804.

3. Mengel A, Ulm L, Hotter B, Harms H, Piper SK, Grittner U, Montaner J, Meisel C, Meisel A, Hoffmann $\mathrm{S}$, Biomarkers of immune capacity, infection and inflammation are associated with poor outcome and mortality after stroke - The PREDICT study. BMC Neurology, 2019; 19(1): 148: 1-10.

4. Sahan M, Sebe A, Acikalin A, Akpinar O, Koc F, Ay MO, Gulen M, Topal M, Satar S, Acute-phase reactants and cytokines in ischemic stroke: Do they have any relationship with short-term mortality? Eur Rev Med Pharm Sci., 2013; 17(20): 2773-2777.

5. Frøyshov HM, Bjørnerem Å, Engstad T, Halvorsen DS, Elevated inflammatory markers predict mortality in long-term ischemic stroke-survivors: a populationbased prospective study. Aging Clin Exp Res., 2017; 29(3): 379-385.

6. Bustamante A, Sobrino T, Giralt D, Garcia-Berrocoso T, Llombart V, Ugarriza I, Espadaler M, Rodriguez N, Sudlow C, Castellanos M, Smith CJ, RodriguezYanez M, Waje-Andreassen U, Tanne D, Oto J, Barber M, Worthmann H, Wartenberg KE, Becker KJ, Chakraborty B, Prognostic value of blood interleukin-6 in the prediction of functional outcome after stroke: A systematic review and meta-analysis. $J$ Neuroimmunol., 2014; 274(1-2): 215-224.

7. Dieplinger B, Bocksrucker C, Egger M, Eggers C, Haltmayer M, Mueller T, Prognostic value of inflammatory and cardiovascular biomarkers for prediction of 90-day all-cause mortality after acute ischemic stroke-results from the Linz stroke unit study. Clin Chem., 2017; 63(6): 1101-1109.

8. Whiteley W, Jackson C, Lewis S, Lowe G, Rumley A, Sandercock P, Wardlaw J, Dennis M, Sudlow $\mathrm{C}$, Inflammatory markers and poor outcome after stroke: A prospective cohort study and systematic review of interleukin-6. PLoS Med., 2009; 6(9): e1000145: 1-12.

9. Smith CJ, Emsley HC, Gavin CM, Georgiou RF, Vail A, Barberan EM, del Zoppo GJ, Hallenbeck JM, Rothwell NJ, Hopkins SJ, Tyrrell PJ, Peak plasma interleukin-6 and other peripheral markers of inflammation in the first week of ischaemic stroke correlate with brain infarct volume, stroke severity and long-term outcome. BMC Neurol., 2004; 4: $2: 1-8$.

10. Rallidis LS, Vikelis M, Panagiotakos DB, Rizos I, Zolindaki MG, Kaliva K, Kremastinos DT, Inflammatory 
markers and in-hospital mortality in acute ischaemic stroke. Atherosclerosis, 2006; 189(1): 193-197.

11. Clark WM, Rinker LG, Lessov NS, Hazel K, Hill JK, Stenzel-Poore M, Lack of interleukin-6 expression is not protective against focal central nervous system ischemia. Stroke, 2000; 31(7): 1715-1720.

12. Duffy SA, Taylor JM, Terrell JE, Islam M, Li Y, Fowler KE, Wolf GT , Teknos TN, Interleukin-6 predicts recurrence and survival among head and neck cancer patients. Cancer, 2008; 113(4): 750-757.

13. Danesh J, Kaptoge S, Mann AG, Sarwar N, Wood A, Angleman SB, Wensley F, Higgins JP, Lennon L, Eiriksdottir G, Rumley A, Whincup PH, Lowe GD, Gudnason V, Long-term interleukin-6 levels and subsequent risk of coronary heart disease: two new prospective studies and a systematic review. PLoS Med., 2008; 5(4): e78: 1-11.

14. Kwan J, Horsfield G, Bryant T, Gawne-Cain M, Durward G, Byrne CD, Englyst NA, IL-6 is a predictive biomarker for stroke associated infection and future mortality in the elderly after an ischemic stroke. Exp Gerontol., 2013; 48(9): 960-965.

15. Greisenegger S, Segal HC, Burgess AI, Poole DL, Mehta Z, Rothwell PM, Biomarkers and mortality after transient ischemic attack and minor ischemic stroke: population-based study. Stroke, 2015; 46(3): 659-666.

16. The Joanna Briggs Institute Critical Appraisal Checklist http://joannabriggs.org.

17. Poorzand $\mathrm{H}$, Tsarouhas $\mathrm{K}$, Hozhabrossadati SA, Khorrampazhouh N, Bondarsahebi Y, Bacopoulou F, Rezaee R, Jafarzadeh Esfehani R, Morovatdar N, Risk factors of premature coronary artery disease in Iran: A systematic review and meta-analysis. Eur J Clin Invest., 2019; 49(7): e13124: 1-13.

18. Chamorro Á, Amaro S, Vargas M, Obach V, Cervera Á, Gómez-Choco M, Torres F, Planas AM, Catecholamines, infection, and death in acute ischemic stroke. Neurol Sci., 2007; 252(1): 29-35.

19. Gori AM, Giusti B, Piccardi B, Nencini P, Palumbo V, Nesi M, Nucera A, Pracucci G, Tonelli P, Innocenti E, Sereni A, Sticchi E, Toni D, Bovi P, Guidotti M, Tola MR, Consoli D, Micieli G, Tassi R, Orlandi G, Sessa M, Perini F, Delodovici ML, Zedde ML, Massaro F, Abbate R, Inzitari D, Inflammatory and metalloproteinases profiles predict three-month poor outcomes in ischemic stroke treated with thrombolysis. J Cereb Blood Flow Metab., 2017; 37(9): 3253-3261.

20. Shenhar-Tsarfaty S, Assayag EB, Bova I, Shopin L, Berliner S, Shapira I, Bornstein NM, Early signaling of inflammation in acute ischemic stroke: clinical and rheological implications. Thromb Res., 2008; 122(2): 167-173.

21. Lasek-Bal A, Jedrzejowska-Szypulka H, Student S, Warsz-Wianecka A, Zareba K, Puz P, Bal W, Pawletko K, Lewin-Kowalik J, The importance of selected markers of inflammation and blood-brain barrier damage for short-term ischemic stroke prognosis. $J$ Physiol Pharmacol., 2019; 70(2): 209-217.

22. Mechtouff L, Bochaton T, Paccalet A, Da Silva CC, Buisson M, Amaz C, Derex L, Ong E,
Berthezene Y, Eker OF, Association of Interleukin6 levels and futile reperfusion after mechanical thrombectomy. Neurology, 2020; 96(5): e752-e757.

23. Dziedzic T, Systemic inflammation as a therapeutic target in acute ischemic stroke. Exp Rev Neurother., 2015; 15(5): 523-531.

24. Sabău M, Țica $\mathrm{O}$, Chețan F, Țica $\mathrm{O}$, Comănescu A, Antal L, Mureșan M, Enăchescu V, Diaconu C, Bidian C, Real life anticoagulant treatment for stroke prevention in patients with nonvalvular atrial fibrillation. Farmacia, 2020; 68(5): 912-918.

25. Esenwa CC, Elkind MS, Inflammatory risk factors, biomarkers and associated therapy in ischaemic stroke. Nat Rev Neurol., 2016; 12(10): 594-604.

26. Whiteley W, Wardlaw J, Dennis M, Lowe G, Rumley A, Sattar N, Welsh P, Green A, Andrews $\mathrm{M}$, Sandercock $\mathrm{P}$, The use of blood biomarkers to predict poor outcome after acute transient ischemic attack or ischemic stroke. Stroke, 2012; 43(1): 86-91.

27. Wartenberg KE, Stoll A, Funk A, Meyer A, Schmidt JM, Berrouschot J, Infection after acute ischemic stroke: risk factors, biomarkers, and outcome. Stroke Res Treat., 2011; 2011: 830614.

28. Singh-Manoux A, Shipley MJ, Bell JA, Canonico M, Elbaz A, Kivimaki M, Association between inflammatory biomarkers and all-cause, cardiovascular and cancer-related mortality. Cmaj., 2017; 189(10): e384-e390.

29. Aulin J, Siegbahn A, Hijazi Z, Ezekowitz MD, Andersson U, Connolly SJ, Huber K, Reilly PA, Wallentin L, Oldgren J, Interleukin-6 and C-reactive protein and risk for death and cardiovascular events in patients with atrial fibrillation. Am Heart J., 2015; 170(6): 1151-1160.

30. Fassbender K, Rossol S, Kammer T, Daffertshofer M, Wirth S, Dollman M, Hennerici M, Proinflammatory cytokines in serum of patients with acute cerebral ischemia: kinetics of secretion and relation to the extent of brain damage and outcome of disease. $J$ Neurol Sci., 1994; 122(2): 135-139.

31. Vila N, Castillo J, Dávalos A, Chamorro A, Proinflammatory cytokines and early neurological worsening in ischemic stroke. Stroke, 2000; 31(10): 2325-2329.

32. Basic Kes V, Simundic A-M, Nikolac N, Topic E, Demarin V, Pro-inflammatory and anti-inflammatory cytokines in acute ischemic stroke and their relation to early neurological deficit and stroke outcome. Clin Biochem., 2008; 41(16): 1330-1334.

33. Christensen H, Boysen G, Johannesen HH, Christensen E, Bendtzen K, Deteriorating ischaemic stroke: cytokines, soluble cytokine receptors, ferritin, systemic blood pressure, body temperature, blood glucose, diabetes, stroke severity, and CT infarction-volume as predictors of deteriorating ischaemic stroke. J Neurol Sci., 2002; 201(1): 1-7.

34. Winovich DT, Longstreth WT, Arnold AM, Varadhan R, Al Hazzouri AZ, Cushman M, Newman AB, Odden MC, Factors Associated With Ischemic Stroke Survival and Recovery in Older Adults. Stroke, 2017; 48(7): 1818-1826. 